\title{
Gramella portivictoriae sp. nov., a novel member of the family Flavobacteriaceae isolated from marine sediment
}

\author{
Stanley C. K. Lau, ${ }^{1}$ Mandy M. Y. Tsoi, ${ }^{1}$ Xiancui Li, ${ }^{1}$ loulia Plakhotnikova, ${ }^{1}$ \\ Sergey Dobretsov, ${ }^{1}$ Po-Keung Wong ${ }^{2}$ and Pei-Yuan Qian ${ }^{1}$ \\ ${ }^{1}$ Coastal Marine Laboratory/Department of Biology, The Hong Kong University of Science and \\ Technology, Clear Water Bay, Kowloon, Hong Kong SAR \\ ${ }^{2}$ Department of Biology, The Chinese University of Hong Kong, Shatin, New Territories, \\ Hong Kong SAR
}

Correspondence

Pei-Yuan Qian

boqianpy@ust.hk
A yellow-pigmented, Gram-negative, slowly gliding, rod-shaped, strictly aerobic bacterium (UST040801-001 ${ }^{\top}$ ) was isolated from marine sediment. The DNA G + C content was $39.9 \mathrm{~mol} \%$. The predominant fatty acids were a15:0, i15:0, i15:0 3-OH, i17: $1 \omega 9 c, \mathrm{i} 17: 03-\mathrm{OH}$ and summed feature 3, comprising i15:0 2-OH and/or $16: 1 \omega 7 c$ (altogether representing $76 \cdot 2 \%$ of the total). MK-6 was the only respiratory quinone. Flexirubin-type pigments were not produced. Phylogenetic analysis based on 16S rRNA gene sequences indicated that Gramella echinicola KMM $6050^{\top}$ (the only species in the genus) was the closest relative of UST040801-001 ${ }^{\top}$, sharing $98.0 \%$ sequence similarity. The DNA-DNA relatedness between UST040801-001 ${ }^{\top}$ and Gramella echinicola KMM $6050^{\top}$ was $13 \%$. Strain UST040801-001 ${ }^{\top}$ can be distinguished from $G$. echinicola by means of 11 phenotypic traits. The results of molecular and phenotypic analyses suggested that UST040801-001 ${ }^{\top}$ represents a novel species of Gramella. The name Gramella portivictoriae sp. nov. is proposed for this bacterium, with UST040801-001 ${ }^{\top}$ $\left(=\right.$ NRRL $\left.41137^{\top}=\mathrm{JCM} 13192^{\top}\right)$ as the type strain.
The genus Gramella, belonging to the family Flavobacteriaceae (Bernardet et al., 1996), was created recently by Nedashkovskaya et al. (2005) and currently consists of a single species, Gramella echinicola, originating from the sea urchin Strongylocentrotus intermedius in the Sea of Japan. In this study, we propose a novel species of Gramella originating from marine sediment.

During the characterization of a microbial community in marine sediment collected from Victoria Harbour, Hong Kong, the bacterial strain UST040801-001 ${ }^{\mathrm{T}}$ was isolated on an agar medium composed of 5 g peptone $1^{-1}, 3$ g yeast extract $1^{-1}$ (both Oxoid) and $0 \cdot 22-\mu \mathrm{m}$-filtered sea water (referred to as marine agar hereafter). After $48 \mathrm{~h}$ incubation at $30{ }^{\circ} \mathrm{C}$ on marine agar, UST040801-001 ${ }^{\mathrm{T}}$ appeared as yellow, convex, circular colonies (2-4 $\mathrm{mm}$ in diameter) with smooth surfaces and entire translucent margins. No

Published online ahead of print on 29 July 2005 as DOI 10.1099/ ijs.0.63824-0.

The GenBank/EMBL/DDBJ accession number for the 16S rRNA gene sequence of strain UST040801-001 ${ }^{\top}$ is DQ002871.

An electron micrograph of cells of strain UST040801-001 ${ }^{\top}$, the results of API 20E, API 20NE and API ZYM tests and details of the carbon sources tested are available as supplementary material in IJSEM Online. diffusible pigment was observed. Unless otherwise specified, all characteristics described hereafter were based on cultures grown on marine agar for $48 \mathrm{~h}$ at $30^{\circ} \mathrm{C}$.

The nearly-complete 16S rRNA gene sequence of UST040801-001 ${ }^{\mathrm{T}}$ (1468 bp) was obtained using a dye terminator method, as described elsewhere (Lau et al., 2004). Fragments of DNA sequence obtained from individual primers with at least six replicates were each assembled using the SEQUENCHER software package (Gene Codes). Comparison of the nearly-complete $16 \mathrm{~S}$ rRNA gene sequence of UST040801-001 ${ }^{\mathrm{T}}$ with those available from GenBank revealed that UST040801-001 ${ }^{\mathrm{T}}$ was a member of the family Flavobacteriaceae and was closely related to $G$. echinicola $\mathrm{KMM} 6050^{\mathrm{T}}$ (98.0 \% sequence similarity) and to the uncharacterized marine bacteria KT0803 and KMM 6048 ( $97 \cdot 8$ and $98 \cdot 4 \%$ sequence similarity, respectively). A neighbour-joining phylogenetic tree constructed using the ARB software package (Ludwig et al., 2004) showed that the four bacteria formed a distinctive clade (Fig. 1). Within this clade, UST040801-001 ${ }^{\mathrm{T}}$ formed a branch with the marine bacterium KMM 6048 without significant bootstrap support. Trees based on maximum-parsimony and maximumlikelihood methods in the ARB software package showed identical topology (Fig. 1). The level of DNA-DNA relatedness between UST040801-001 ${ }^{\mathrm{T}}$ and G. echinicola KMM 


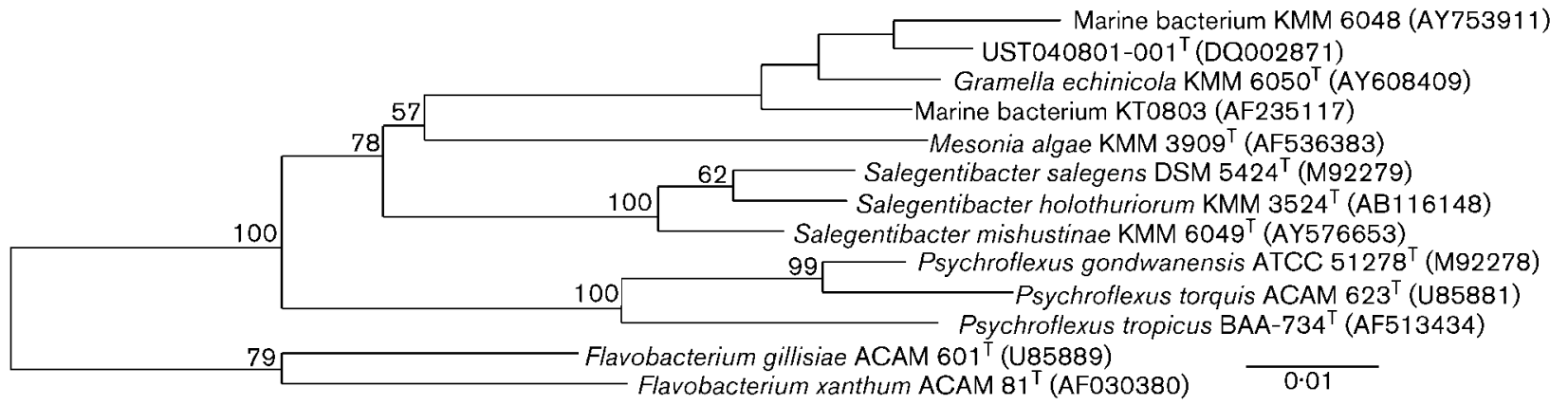

Fig. 1. Neighbour-joining tree showing the estimated phylogenetic relationships among UST040801-001 ${ }^{\top}$ and related species, on the basis of $16 \mathrm{~S}$ rRNA gene sequences. Strains belonging to the genus Flavobacterium served as outgroups. The topologies of the trees constructed using maximum-parsimony and maximum-likelihood methods were identical to the topology in the neighbour-joining tree (not shown). Bootstrap values above $50 \%$ (500 replicates) are indicated at nodes. GenBank accession numbers are shown in parentheses. Bar, 1 nt substitution per 100 nt.

$6050^{\mathrm{T}}$ was $13 \%$, which clearly indicated that UST040801$001^{\mathrm{T}}$ should belong to a novel species of the genus Gramella. DNA-DNA hybridization experiments were performed by the BCCM/LMG Bacteria Collection, Laboratorium voor Microbiologie, Universiteit Gent (Gent, Belgium) using photobiotin-labelled probes as described by Ezaki et al. (1989).

The DNA G + C content of UST040801-001 ${ }^{\mathrm{T}}$, determined using an HPLC method (Mesbah et al., 1989), was 39.9 \pm $0.2 \mathrm{~mol} \%$ (three replicates). This value was similar to that for G. echinicola KMM $6050^{\mathrm{T}}(39 \cdot 6 \mathrm{~mol} \%)$. The dominant cellular fatty acids of UST040801-001 ${ }^{\mathrm{T}}$ were a $15: 0, \mathrm{i} 15: 0$, i15: $03-\mathrm{OH}, \mathrm{i} 17: 1 \omega 9 c$, i1 $7: 03-\mathrm{OH}$ and summed feature 3, comprising i15:0 2-OH and/or $16: 1 \omega 7 c$ (altogether representing $76 \cdot 2 \%$ of the total), as determined using the Sherlock Microbial Identification System (MIDI) according to the manufacturer's protocol (Table 1). MK-6 was the only respiratory quinone, as determined using an HPLC method according to Collins (1994). Menaquinones extracted from Cellulophaga lytica (Johansen et al., 1999) and Pedobacter heparinus (Steyn et al., 1998) served as references for MK-6 and MK-7, respectively.

Anaerobic growth was examined using the Oxoid Anaerobic System. The requirement for $\mathrm{NaCl}$ was tested in a medium containing $\left(1^{-1}\right) 5 \mathrm{~g} \mathrm{MgCl}_{2}, 2 \mathrm{~g} \mathrm{MgSO}_{4}, 0.5 \mathrm{~g} \mathrm{CaCl}_{2}, 1 \mathrm{~g}$ $\mathrm{KCl}, 5 \mathrm{~g}$ peptone and various amounts of $\mathrm{NaCl}$, adjusted to $\mathrm{pH} 7 \cdot 5$ using $\mathrm{KOH}$ (Isnansetyo \& Kamei, 2003). Cell morphology was examined using scanning electron microscopy (7600F; JEOL) according to Neu et al. (2001) (see Supplementary Fig. S1 available in IJSEM Online). The reaction to Gram stain was determined using light microscopy according to Smibert \& Krieg (1994). Gliding motility was determined using phase-contrast light microscopy (Olympia) after growth on quarter-strength marine 2216 medium (Oxoid) solidified with $1 \%$ agar according to Bowman (2000). Susceptibility to antibiotics was tested as described by Acar (1980). Flexirubin-type pigment production and carboxymethylcellulose hydrolysis were determined as described by Bernardet et al. (2002). Casein

Table 1. Cellular fatty acid profiles of UST040801-001 ${ }^{\top}$ and G. echinicola $\mathrm{KMM} 6050^{\top}$

Values are percentages of total fatty acids. Data for UST040801-001 ${ }^{\mathrm{T}}$ are means \pm SD (three replicates). Data for G. echinicola KMM $6050^{\mathrm{T}}$ are from Nedashkovskaya et al. (2005). Strain UST040801-001 ${ }^{\mathrm{T}}$ was grown in marine agar at $30^{\circ} \mathrm{C}$ for $48 \mathrm{~h}$, whereas G. echinicola $\mathrm{KMM}$ $6050^{\mathrm{T}}$ was grown in marine agar 2216 at $25^{\circ} \mathrm{C}$ for $48 \mathrm{~h}$.

\begin{tabular}{|lcc|}
\hline Fatty acid & UST040801-001 $^{\text {T }}$ & $\begin{array}{c}\text { Gramella echinicola } \\
\text { KMM } \mathbf{6 0 5 0}\end{array}$ \\
\hline i13:0 & $0 \cdot 8 \pm 0 \cdot 1$ & - \\
i14:0 & $0 \cdot 5 \pm 0 \cdot 1$ & $1 \cdot 4$ \\
$15: 0$ & - & $7 \cdot 1$ \\
$15: 1 \omega 6 c$ & $1 \cdot 8 \pm 0 \cdot 3$ & $1 \cdot 9$ \\
a15:0 & $6 \cdot 2 \pm 0 \cdot 7$ & $7 \cdot 6$ \\
i15:0 & $38 \cdot 1 \pm 0 \cdot 5$ & $14 \cdot 4$ \\
i15: 1 & - & $1 \cdot 2$ \\
i16:0 & $1 \cdot 9 \pm 0 \cdot 4$ & $13 \cdot 1$ \\
i16:1 & - & $5 \cdot 8$ \\
i16:1 H & $0 \cdot 9 \pm 0 \cdot 1$ & - \\
$15: 0$ 2-OH & $1 \cdot 0 \pm 0 \cdot 2$ & $2 \cdot 0$ \\
$15: 03-\mathrm{OH}$ & $2 \cdot 5 \pm 0 \cdot 1$ & - \\
i15:0 3-OH & $6 \cdot 2 \pm 0 \cdot 3$ & $1 \cdot 3$ \\
i16:0 3-OH & $3 \cdot 4 \pm 0 \cdot 3$ & $5 \cdot 9$ \\
$17: 0$ 2-OH & $1 \cdot 5 \pm 0 \cdot 2$ & $2 \cdot 6$ \\
$17: 1 \omega 6 c$ & $1 \cdot 7 \pm 0 \cdot 3$ & $3 \cdot 6$ \\
a17: $1 \omega 9 c$ & - & $2 \cdot 0$ \\
i17: $1 \omega 9 c$ & $5 \cdot 7 \pm 1 \cdot 3$ & $3 \cdot 5$ \\
i17:0 3-OH & $11 \cdot 2 \pm 0 \cdot 3$ & $6 \cdot 7$ \\
$18: 1 \omega 5 c$ & $1 \cdot 0 \pm 0 \cdot 1$ & - \\
Summed feature $3 *$ & $8 \cdot 8 \pm 1 \cdot 2$ & $4 \cdot 6$ \\
Unknown & $6 \cdot 3 \pm 1 \cdot 6$ & \\
\hline
\end{tabular}

${ }^{\star}$ Comprises i15:0 2-OH and/or 16:1 $\omega 7 c$. 
hydrolysis was determined as described by Norris et al. (1985); Tween 20, 40 and 80 hydrolysis and chitin were tested as described by Baumann \& Baumann (1988). Spore formation, oxidase and catalase activities and the hydrolysis of agar, DNA and starch were tested as described by Smibert \& Krieg (1994). Other enzymic activities, the substrateutilization profile, nitrate reduction and the production of $\mathrm{H}_{2} \mathrm{~S}$, indole and acetoin were tested using the commercial systems API 20E, API 20NE, API $50 \mathrm{CH}$ and API ZYM (all from bioMérieux) and MicroLog 3 (Biolog). Cells for inoculation to the API systems were suspended in a sterile solution of sea-water mix at $22 \%$ salinity (MacDonell et al., 1982). Growth on D-arabinose, D-galactose, D-glucose, glycerol, D-mannitol, D-melibiose, D-sorbitol, starch and sucrose as sole carbon sources was additionally tested using a medium that contained $0 \cdot 2 \mathrm{~g} \mathrm{NaNO}_{3} \mathrm{l}^{-1}, 0 \cdot 2 \mathrm{~g} \mathrm{NH}_{4} \mathrm{Cl} \mathrm{l}^{-1}$, $0.05 \mathrm{~g}$ yeast extract $\mathrm{l}^{-1}$ and $4 \%(\mathrm{w} / \mathrm{v})$ carbon source in a solution of sea-water mix at $35 \%$ salinity (Nedashkovskaya et al., 2003). The phenotypic characteristics of UST040801$001^{\mathrm{T}}$ are given in the species description (and in Supplementary Table S1, available in IJSEM Online).

Strain UST040801-001 ${ }^{\mathrm{T}}$ can be distinguished from $G$. echinicola by (i) the absence of $\beta$-galactosidase activity; (ii) the ability to hydrolyse Tween 20 , to produce acetoin and to utilize D-mannitol and D-sorbitol; and (iii) the inability to grow in $15 \% \mathrm{NaCl}$ and to hydrolyse casein and DNA (Table 2). The results of molecular analysis, together with the phenotypic characteristics, suggest that strain UST040801-001 ${ }^{\mathrm{T}}$ represents a novel species of the genus Gramella.

\section{Description of Gramella portivictoriae sp. nov.}

Gramella portivictoriae (por'ti.vic.to'ri.ae. L. n. portus harbour; L. gen. fem. n. victoriae of Victoria; N.L. gen. fem. n. portivictoriae from/of Victoria Harbour, Hong Kong, the source of isolation of the type strain).

Table 2. Differentiation of UST040801-001 ${ }^{\top}$ from G. echinicola KMM $6050^{\top}$

Data for G. echinicola KMM $6050^{\mathrm{T}}$ are from Nedashkovskaya et al. (2005).

\begin{tabular}{|lcc|}
\hline Characteristic & UST040801-001 $^{\mathbf{T}}$ & $\begin{array}{c}\text { G. echinicola } \\
\text { KMM } \mathbf{6 0 5 0}\end{array}$ \\
\hline Growth in $15 \% \mathrm{NaCl}$ & - & + \\
Hydrolysis of: & - & + \\
Casein & - & + \\
DNA & + & - \\
Tween 20 & - & + \\
$\beta$-Galactosidase activity & + & - \\
Production of acetoin & & - \\
Utilization of: & + & - \\
D-Mannitol & + & \\
D-Sorbitol & & \\
\hline
\end{tabular}

Cells are Gram-negative, rod-shaped $(0 \cdot 6-3 \cdot 6 \mu \mathrm{m})$, glide slowly and do not form spores. Colonies on marine agar are yellow in colour without diffusible pigment, circular, $2 \cdot 0-4 \cdot 0 \mathrm{~mm}$ in diameter and convex with smooth surfaces and entire translucent margins after $48 \mathrm{~h}$ at $30.0{ }^{\circ} \mathrm{C}$. Growth is strictly aerobic and occurs between 4.0 and $36.0{ }^{\circ} \mathrm{C}$ $\left(28 \cdot 0-30 \cdot 0{ }^{\circ} \mathrm{C}\right.$ optimum), at $\mathrm{pH} 6 \cdot 0-10 \cdot 0$ (pH 7.0-8.0 optimum) and at $1 \cdot 0-6 \cdot 0 \% \mathrm{NaCl}$. The DNA G $+\mathrm{C}$ content is $39.9 \mathrm{~mol} \%$. The predominant cellular fatty acids are a15:0, i15:0, i15:0 3-OH, i17: $1 \omega 9 c$, i17:0 $3-\mathrm{OH}$ and summed feature 3 , comprising i15:0 $2-\mathrm{OH}$ and/or $16: 1 \omega 7 c$ (altogether representing $76 \cdot 2 \%$ of the total). The major quinone is MK-6. Flexirubin-type pigments are not produced. Susceptible to ampicillin, chloramphenicol, penicillin and tetracycline, but not to kanamycin or streptomycin. Acetoin is produced, but indole and $\mathrm{H}_{2} \mathrm{~S}$ are not. Citrate is not utilized. Nitrate is not reduced. Aesculin ferric citrate, gelatin, starch and Tweens 20, 40 and 80 are hydrolysed, but agar, casein, carboxymethylcellulose, chitin and DNA are not hydrolysed. Positive for acid phosphatase, alkaline phosphatase, $\alpha$-chymotrypsin, catalase, cystine arylamidase, leucine arylamidase, valine arylamidase, esterase (C4), esterase lipase (C8), lipase (C14), oxidase, $\alpha$-galactosidase, $\alpha$-glucosidase, $\beta$ glucosidase, trypsin and naphthol-AS-BI-phosphohydrolase activities. Negative for $N$-acetyl- $\beta$-glucosaminidase, arginine dihydrolase, $\alpha$-fucosidase, $\beta$-galactosidase, $\beta$-glucuronidase, $\alpha$-mannosidase, lysine decarboxylase, ornithine decarboxylase, tryptophan deaminase and urease activities. Utilization of D-arabinose, D-galactose, D-glucose, glycerol, D-mannitol, D-melibiose, D-sorbitol, starch and sucrose as sole carbon sources is observed on agar medium supplemented with $4 \%$ $(\mathrm{w} / \mathrm{v})$ carbon source. Utilization of $\gamma$-hydroxybutyric acid is observed with the MicroLog 3 system. However, no growth or acid production is observed from the carbon sources in the API $50 \mathrm{CH}$, API 20E and API 20NE test systems (lists of carbon sources included in the API and MicroLog 3 test systems are available in Supplementary Tables S2 and S3, respectively, in IJSEM Online.)

The type strain is UST040801-001 ${ }^{\mathrm{T}}\left(=\mathrm{NRRL} 41137^{\mathrm{T}}=\mathrm{JCM}\right.$ $\left.13192^{\mathrm{T}}\right)$, isolated from sediment in Victoria Harbour, Hong Kong.

\section{Acknowledgements}

The authors thank Mr Ken Lau for respiratory quinone analysis and Professor Hans G. Trüper for assistance with the Latin etymology. This work was supported by grants from the Research Grants Council (CA04/05.Sc01) and the Area of Excellence Scheme of the University Grants Committee (AoE/O-04/2004) to P.-Y.Q.

\section{References}

Acar, J. F. (1980). The disc susceptibility test. In Antibiotics in Laboratory and Medicine, pp. 24-54. Edited by V. Lorian. Baltimore: Williams \& Wilkins.

Baumann, P. \& Baumann, L. (1988). The marine Gram-negative eubacteria: genera Photobacterium, Beneckea, Alteromonas, Pseudomonas and Alcaligenes. In The Prokaryotes, 2nd edn, vol. 1, 
pp. 1302-1331. Edited by M. P. Starr, H. Stolp, H. G. Trüper, A. Balows \& H. Schlegel. New York: Springer.

Bernardet, J. F., Segers, P., Vancanneyt, M., Berthe, F., Kersters, K. \& Vandamme, P. (1996). Cutting a Gordian knot: emended classification and description of the genus Flavobacterium, emended description of the family Flavobacteriaceae, and proposal of Flavobacterium hydatis nom. nov. (basonym, Cytophaga aquatilis Strohl and Tait 1978). Int J Syst Bacteriol 46, 128-148.

Bernardet, J. F., Nakagawa, Y. \& Holmes, B. (2002). Proposed minimal standards for describing new taxa of the family Flavobacteriaceae and emended description of the family. Int J Syst Evol Microbiol 52, 1049-1070.

Bowman, J. P. (2000). Description of Cellulophaga algicola sp. nov., isolated from the surfaces of Antarctic algae, and reclassification of Cytophaga uliginosa (ZoBell and Upham 1944) Reichenbach 1989 as Cellulophaga uliginosa comb. nov. Int J Syst Evol Microbiol 50, 1861-1868.

Collins, M. D. (1994). Isoprenoid quinones. In Chemical Methods in Prokaryotic Systematics, pp. 265-310. Edited by M. Goodfellow \& A. G. O'Donnell. Chichester: Wiley.

Ezaki, T., Hashimoto, Y. \& Yabuuchi, E. (1989). Fluorometric deoxyribonucleic acid-deoxyribonucleic acid hybridization in microdilution wells as an alternative to membrane filter hybridization in which radioisotopes are used to determine genetic relatedness among bacterial strains. Int J Syst Bacteriol 39, 224-229.

Isnansetyo, A. \& Kamei, Y. (2003). Pseudoalteromonas phenolica sp. nov., a novel marine bacterium that produces phenolic antimethicillin-resistant Staphylococcus aureus substances. Int J Syst Evol Microbiol 53, 583-588.

Johansen, J. E., Nielsen, P. \& Sjoholm, C. (1999). Description of Cellulophaga baltica gen. nov., sp. nov. and Cellulophaga fucicola gen. nov., sp. nov. and reclassification of [Cytophaga] lytica to Cellulophaga lytica gen. nov., comb. nov. Int J Syst Bacteriol 49, 1231-1240.

Lau, S. C. K., Tsoi, M., Li, X., Plakhotnikova, I., Wu, M., Wong, P. K. \& Qian, P. Y. (2004). Loktanella hongkongensis sp. nov., a new member of the $\alpha$-Proteobacteria originating from marine biofilms in Hong Kong waters. Int J Syst Evol Microbiol 54, 2281-2284.

Ludwig, W., Strunk, O., Westram, R. \& 29 other authors (2004). ARB: a software environment for sequence data. Nucleic Acids Res 32, 1363-1371.

MacDonell, M. T., Singleton, F. L. \& Hood, M. A. (1982). Diluent composition for use of API $20 \mathrm{E}$ in characterizing marine and estuarine bacteria. Appl Environ Microbiol 44, 423-427.

Mesbah, M., Premachandran, U. \& Whitman, W. B. (1989). Precise measurement of the $\mathrm{G}+\mathrm{C}$ content of deoxyribonucleic acid by highperformance liquid chromatography. Int J Syst Bacteriol 39, 159-167.

Nedashkovskaya, O. I., Kim, S. B., Han, S. K. \& 7 other authors (2003). Mesonia algae gen. nov., sp. nov., a novel marine bacterium from the green alga Acrosiphonia sonderi (Kütz) Konm. Int J Syst Evol Microbiol 53, 1967-1971.

Nedashkovskaya, O. I., Kim, S. B., Lysenko, A. M., Frolova, G. M., Mikhailov, V. V., Bae, K. S., Lee, D. H. \& Kim, I. S. (2005). Gramella echinicola gen. nov., sp. nov., a novel halophilic bacterium of the family Flavobacteriaceae isolated from the sea urchin Strongylocentrotus intermedius. Int J Syst Evol Microbiol 55, 391-394.

Neu, B., Voigt, A., Mitlohner, R. \& 7 other authors (2001). Biological cells as templates for hollow microcapsules. J Microencapsul 18, 385-395.

Norris, J. R., Ribbons, D. W. \& Varma, A. K. (editors) (1985). Methods in Microbiology, vol. 18. London: Academic Press.

Smibert, R. M. \& Krieg, N. R. (1994). Phenotypic characteristics. In Methods for General and Molecular Biology, pp. 607-654. Edited by P. Gerhardt, R. G. E. Murray, W. A. Wood \& N. R. Krieg. Washington, DC: American Society for Microbiology.

Steyn, P. L., Segers, P., Vancanneyt, M., Sandra, P., Kersters, K. \& Joubert, J. J. (1998). Classification of heparinolytic bacteria into a new genus, Pedobacter, comprising four species: Pedobacter heparinus comb. nov., Pedobacter piscium comb. nov., Pedobacter africanus sp. nov. and Pedobacter saltans sp. nov. Proposal of the family Sphingobacteriaceae fam. nov. Int J Syst Bacteriol 48, 165-177. 